\title{
THE IMAGE OF THE EUROPEANS IN HIKAYAT MARESKALEK
}

\author{
(Imej Orang Eropah dalam Hikayat Mareskalek)
}

\author{
Noriah Taslim \\ tnoriah@gmail.com
}

Faculty of Arts and Social Sciences, University of Brunei Darussalam, Brunei Darussalam.

\begin{abstract}
This article discusses the Hikayat Mareskalek as a work of etiquette literature intended to instruct the Malay rulers through a European character. The 18 th/19th centuries were a time that saw the emergence of not only new types of writing but also new genres modelled on those introduced by the Europeans; the date of production of this hikayat falls during this time. Under the influence and patronage of Europe, transitional works such as these display a pro-European tendency in terms of the narrative point of view and he orientation of thought. However, fascination with Europe was not in fact total. Hikayat Mareskalek (Maarschalk Willem Daendels), written by Abdullah al-Misri in Pontianak in 1815, is one of the works that does not display such a tendency. Although this hikayat mentions a European in its title, he is not the subject of the narrative; instead the writer cleverly exploits and manipulates his characteristics, attitudes and actions to act as a "mirror" reflection for the Malay rulers.
\end{abstract}

Keywords: Hikayat Mareskalek, Maarschalk Willem Daendels, etiquette genre, Abdullah al-Misri, reflection of Malay rulers

\section{Abstrak}

Makalah ini membicarakan Hikayat Mareskalek sebagai sebuah genre adab yang mengajar raja-raja Melayu melalui watak dan perwatakan seorang pentadbir Eropah. Hikayat ini ditulis pada abad ke-18/19, iaitu abad yang menyaksikan kemunculan bukan sahaja bentuk kepengarangan jenis-jenis baharu tetapi juga pengenalan genre baharu yang bermodelkan 
bentuk penulisan yang diperkenalkan orang Eropah. Di bawah pengaruh dan naungan Eropah, karya transisi memperlihatkan kecenderungan untuk bersifat pro-Eropah dari sudut subjek penceritaan dan orientasi pemikiran. Namun, fenomena pesona Eropah ini sebenarnya tidak berlaku secara menyeluruh. Hikayat Mareskalek (Maarschalk Willem Daendals) yang ditulis oleh Abdullah al-Misri di Pontianak pada tahun 1815 ini merupakan antara karya yang tidak memperlihatkan kecenderungan sedemikian. Walaupun hikayat ini menggunakan orang Eropah sebagai judulnya, tetapi tidak menjadikannya subjek penceritaan, sebaliknya dengan bijak mengeksploitasi dan memanipulasi seluruh sifat, sikap dan tindak-tanduknya untuk tujuan menjadi "cermin" kepada raja-raja Melayu.

Kata Kunci: Hikayat Mareskalek, Maarschalk Willem Daendals, genre adab, Abdullah al-Misri, cermin raja-raja Melayu

\section{INTRODUCTION:}

One interesting phenomenon in the history of Malay literature is the emergence of what has been called the transitional period (Skinner, 1978). Its emergence can be seen as the direct result of the meeting of East and West in the Malay world that can be loosely dated to the 18th and 19th centuries (in some places it occurred even earlier). Within this context, the transitional period can be defined as a time of transition of shift in the politics, economy, society and culture of the Malays from an older (traditional or indigenous) form to a modern one. In literary history, specifically, this period has been named the period of "literary renaissance" (Tiwon, 1999). Transitional literature is defined as "literature which reflects and is a product of a society that is in the process of change from traditional to modern" (Murtagh, 2014: 231). Prior to this, Parnickel (1995:111) considered the literature of this transitional period the "sastera perantara yang menghubungkan dunia Nusantara dengan dunia Barat dan tamadunnya" (intermediary literature that connected the world of the Archipelago with the Western world and its civilization).

The meeting of East and West and its overall effects on Malay society, and especially Malay culture, has been discussed at length in other writings (see Noriah, 2015). ${ }^{1}$ This article focuses only on the impact on literary production (writer and writing) in the aforementioned transitional period. Interestingly, in this period, several factors such as sociocultural, and political factors, the media, can be seen to combine and give rise to what has been called a new kind of writing, whose characteristics are no longer palace-centric, more 
expressive, unconventional or untraditional ${ }^{2}$ in nature, thus departing from the cocoon of the palace and the confines of tradition. Literary activities began to move away from the palace, and new writers emerged from the lower classes and the margins. ${ }^{3}$

Most of them were also not pure-blooded Malays. The early palace writers were perhaps of mixed ethnic heritage, for example Ahmad Rijaluddin and Abdullah Munshi, who were of Indian descent; Abdullah al-Misri was of Arab ancestry (see Salmon, 1999). Most of them socialized, were students of or worked for Europeans, among them La'udin, Ahmad Rijaluddin, Abdullah Munshi, Abdullah al-Misri (the writers discussed in this essay), Khatib Lukman, and Hikamat/Marjan. Their contact with the Europeans is responsible for the shift in their creative and literary consciousness, breaking literary conventions, especially in terms of form, genre and literary rules, pioneering the way for a "new" literature.

The fact is that these new writers were on the whole not from the group of traditional palace writers. ${ }^{4}$ Parnickel aims to explain this $(1995: 111)$ :

Pergaulan penulis Melayu (merujuk kepada pengarang istana) dengan orang Barat masih terbatas, kerana sebahagian daripada mereka adalah ahli agama atau orang bangsawan yang terkurung dalam persekitaran sosialnya serta menjauhi segala sesuatu yang berbau Barat dan bukan Muslim. Sebagaimana biasa, orang-orang pinggiranlah (marginal people) yang sedikit demi sedikit mula mendampingi kebudayaan Barat dan pembawanya dan merekalah akhirnya menjadi pembaharu kesusasteraan Melayu.

(The contact between Malay writers (referring to palace writers) and Westerners was still limited, because a number of them were religious scholars or aristocrats who were confined within their social environment and avoided everything that was remotely Western and non-Islamic. As is usual, the marginal people were the ones who slowly approached Western culture and its transmitters, and in the end they were the ones who reformed Malay literature.)

Without the constraints of the palace, and through contact with Europeans, these new writers were also continuously on the move, travelling often; thus, they were exposed to the outside world that they witnessed. ${ }^{5}$ They became more knowledgeable about the world, were more sensitive to the other cultural models that they encountered, and in this fashion they were able to view their own society from the outside - from a distance - and thus from a different perspective. This influenced the ways in which they judged members of their own society. They became more critical and objective. 
However, because traditionally literary activities had to be carried out under patronage, these new writers also needed patrons. Skinner (1978:27) says that the "nonaristocratic artist", as he termed writers like this, " ... was almost entirely dependent on patronage". Therefore, following the trend of the time, literary activities began to lean towards the European "palace" 6 or towards the cities of the Europeans - their centres of power and trade, and their ports. Interestingly, even as they changed patrons, the orientation of their writing did not veer far away from the tendencies of the old writers - in order to maintain patronage, ${ }^{7}$ they still needed to flatter their patrons, as such they aimed to "please" their "white masters". Thus, their writings, while to a certain extent free of the confinements of old conventions and schemata, were nevertheless still skewed, subjective and selective.

Because of the close connection between literary activities and European patronage, most works were produced in the administrative or trade centres of the Europeans, the metaphorical "European palaces" - especially those of the Dutch and British, which had sprung up all over the Malay world - such as Bencoolen, Palembang, Batavia, Deli, Acheh, Singapore, Malacca, Riau, and Makassar, among others.

The impact of the emergence of this new kind of writing in this transitional period can be seen through the development of "new" genres mostly modelled on or inspired by European writings or literary genres. This includes journals and newspapers. Among the earliest genres to have reached the European trading ports in the East is that of the travelogue - records of journeys that were extremely popular among European travellers to the East since the early 13 th century. ${ }^{8}$

The earliest such travelogue may have been Hikayat Perintah Negeri Benggala by Ahmad Rijaluddin, 1810/1811(see Skinner, 1982). This was then followed by Kisah Pelayaran Abdullah, 1838 and Kisah Pelayaran Abdullah ke Mekah, 1858/59 (see Sweeney, 2008) by the most controversial writer of the transitional period, Abdullah Munshi. Slightly before this, there was Syair Peri Tuan Raffles Pergi ke Minangkabau, $1820^{9}$ while later ones were Kisah Pelayaran Muhd Ibrahim Munshi, 1871-1872, by Muhd Ibrahim Munshi (the son of Abdullah Munshi) and Syair Perjalanan Sultan Lingga ke Johor, 1894 by Khalid Hitam.

Another genre was the memoir, or what in this transitional period can be classified as biography and autobiography or self-narrative. Perhaps the earliest Malay biography (about Malays by a Malay writer) ${ }^{10}$ that can be found is Hikayat Nakhoda Muda, 1766, by La'udin (Noriah, forthcoming, 
Yayasan Karyawan). This is followed by a well-known autobiography, Hikayat Abdullah, 1843 (see Sweeney, Vol. 3, 2008); another, shorter one that is much less known is Hikayat Hikamat by Marjan/Hikamat, 1861-1866, a slave from Sumatra who had been rescued by Keasberry in Singapore (see Raimy Che-Ross, 2007). ${ }^{11}$

Another type of writing that appeared during this period is that of the factual or historical narrative, according to its modern definition (see Kathirithamby-Wells, 1980). During this transitional period in the Malay world, this genre emerges mainly in the form of war poems (syair perang). The earliest may be Hikayat Perang Peuringgi (Feringgi, or Portuguese) that dates back to the late 16th century. Others are Syair Sipelman (Speelman, a Dutch official) or Syair Perang Mengkasar by Incik Amin, 1666; Syair Perang Betawi, 1811, by Muhammad Altiff ibn Kadir Muhayuddin; Syair Hemop (van Imhoff, a Dutch official), 1814, by Abdurahaman Banjarmasin; Syair Perang Menteng (also titled Hikayat Muntinghe - after the name of a Dutch official), 1819, by an anonymous writer from Palembang; Syair Perang Johor, 1844 by Raja Ahmad Haji; Hikayat Perang Gompeuni, which dates back to late in the year 1873, by Do Karim (Abdul Karim) from Acheh.

According to Tiwon (1999), war poems became a noticeable feature of literature in the transitional period, or what she has termed the "literary renaissance" in the Indonesian archipelago. Different to other genres written under colonial patronage, which as a result tended to be orientated towards Europe, these war poems did not wholly celebrate Europe, whether in terms of characters, exploits of war or bravery. ${ }^{12}$ Many works were also written to celebrate the Malays or Malay rulers and denigrate the image of the Europeans, presenting them as ugly plunderers. Syair Sipelman or Syair Perang Mengkasar, Syair Perang Menteng, Syair Perang Aceh, and Syair Perang Rokam are examples of poems that are pro-Malay. These poems do contain characters with European names but display distinctly anti-European attitudes - in the texts mentioned above, the enmity is directed against the Dutch (see Muhammad Yusoff, 1991). Tiwon's conclusion from this may aid our understanding about the emergence of war poems (1999:102):

Historical syair ... were written not so much to commemorate ancient kingdoms as to provide responses to the influx of Europeans in their realms.

From this it can be surmised that unlike other works from this transitional period, most war literature was written not to pay homage to European 
patrons or celebrate European figures; instead, these were responses to the European presence in the region.

One of the writers of this transitional period who wrote in this environment, that is, within the context of the European (Dutch and British) presence, and who was familiar with European figures but not inclined to celebrate them, was Abdullah al-Misri. This is reflected in one of his works titled Hikayat Mareskalek. ${ }^{13}$ This text, although centred on a European figure as its main character, is not intended to eulogize, please or flatter him. This article attempts to show other tendencies or viewpoints behind the selection of a European character for this hikayat. The European character is not the subject of this narrative but the object for a different subject.

\section{ABDULLAH AL-MISRI AND HIKAYAT MARESKALEK}

Hikayat Mareskalek (the Zaini-Lajoubert version, 2008) or the tale of Maarschalk Willem Daendels, was written by Abdullah al-Misri, whose full name was Abdullah Muhammad al-Misri, around the year 1815, in Pontianak. Daendels, the title character, was a French officer who was appointed as the Governor-General of the Dutch Indies of Batavia from 1808 to 1811 (for details see Chambert-Loir, 2009). Abdullah al-Misri, who was of mixed Arab descent, is believed to have been born in Kedah around 1790, and passed away in 1845. As was common among Arabs in the region at the time, he later travelled around the Archipelago for trade, especially to Java, and stayed in several places, including Batavia, Kutai, Pontianak, Besuki, Ria and Bali.

As was common among Arabs of the time also, he generally mingled with aristocratic families or the ruling class - something he did while staying in Kutai, Pontianak, Batavia and Bali (see Chambert-Loir, 2009). Thus, while in Pontianak, he was in close contact with the aristocrats of Pontianak; Hikayat Mareskalek was written while he stayed there, to be presented to Sultan Sharif Qasim (the sultan of Pontianak from 1808 to1819) and the sultan's younger brother, Usman.

Zaini-Lajoubert (2008:15) considers Abdullah al-Misri to be "among the innovators of Malay literature" who appeared in the transitional period of the early 19th century. His works, according to Zaini-Lajoubert (2008: 15), can be considered transitional period literature as it is:

... ditandai oleh sejumlah sifat yang khas dan yang baru muncul pada masa itu, antara lain sebagian besar karya itu disebut tahun penulisannya, pengarangnya diketahui, pribadinya tercermin dalam karya-karyanya, 
pengarang memberikan pendapatnya dan melancarkan kritik terhadap para penguasa, dan realisme merupakan ciri yang penting.

(... characterized by a number of new and special features that emerged during that time, among these, a large number of works mention the year of publication, their author is identified, the author's character is reflected in the work, and the author presents his own point of view and criticizes those in power, while realism is an important characteristic.)

In fact, Abdullah al-Misri can be considered as one of the earliest writers of the transitional period, being almost the contemporary of Ahmad Rijaluddin, who produced a narrative titled Hikayat Perintah Negeri Benggala, 1811; and Khatib Lukman who recorded four historical events that took place between 1815 and 1820 in a factual work titled Syair Kerajaan Bima, 1830.

Along with other literary genres that appeared during this period, Hikayat Mareskalek can be considered a historical narrative. The text includes historical, political, social and economic events in Java and other kingdoms in the Malay world during the colonial (Dutch and British) era. Although historical in nature, Abdullah does not function as a historiographer interested in merely recording historical events of the colonial period. The text does not focus on Daendels alone, although using him as its title character but merely presents anecdotes concerning him.

In this hikayat, the title character appears only 20 pages later, and even then his appearance is merely incidental in the narrative, his presence in Batavia attributed to "the Power of Allah sent from above". The aim of the writer is also not to celebrate the European character, although the anecdotes about him do present positive characteristics and are often commended by Abdullah. As will be discussed further on, there is a hidden agenda behind selection of the incidents, stories and anecdotes concerning this character.

As can be seen from his works, especially his major works, Hikayat Mareskalek (1815) and Arsy al-Muluk - Singgahsana Raja-Raja (1818), Abdullah is a keen political observer, a political moralist who rigidly adheres to Islamic principles of political government. In his travels and dealings as a trader, his contact with various Malay communities, including royal families, made Abdullah a traveller who was worldly-wise, culturally aware and a keen observer of human behaviour and politics in his surroundings - whether among the locals or among the colonizers. Both the works mentioned above were written during his travels in the Malay archipelago, and are the outcome 
of Abdullah al-Misri's observations and political thought, and can therefore be categorized as "etiquette" literature or as "mirrors".

In short, Hikayat Mareskalek is a work that functions as a "mirror" for the Malay rulers, a genre inherited from Arab-Persian literature that is known in the Malay world as "kitab ketatanegaraan" or political literature. The nature of the genre, the aim behind its composition and its target audience are explicitly mentioned by Abdullah al-Misri in the introduction to Hikayat Mareskalek:

Ini suatu cetera yang sangat baik diketahui dia, di dalamnya beberapa hikmat dan obat bagi segala raja-raja dan orang yang memerintah negeri, diambil cermin daripada barang yang tersebut di dalam surat ini.

(This is a good tale to be known, in it are several wisdoms and remedies for kings and those who are rulers, to reflect on what is said in this writing.)

This "Mirror for Kings" genre essentially transmits and explains the responsibilities and duties of kings or chiefs. ${ }^{14}$ Such works interweave "history" and "politics" to support the theme of "etiquette" of government. In such works, history is important not for its facts but for the morals that are implied by the historical events and happenings. Old historical figures, even those from ancient history (the Prophets, the companions, caliphs, ministers and heroes) are brought to life, listed as examples to be followed or emulated. Such works are aimed at checking the actions of kings and guide them in their ways of government through the examples of ancient rulers or figures. Because the target audience is rulers and palace officials, such a work was often presented to kings. ${ }^{15}$ Therefore, while Hikayat Mareskalek was written during the colonial period, it was not produced for the European "masters". Hikayat Mareskalek and Arsy al-Muluk were both written for Sultan Sharif Qasim, the sultan of Pontianak.

Abdullah's educational background played an important role in shaping his perceptions and political thought. Apart from being a successful merchant (see Chambert-Loir, 2009), Abdullah was also an Islamic religious scholar and religious intellectual. During his time in Batavia, he came under the tutelage of a well-known sheikh in Java, his cousin, Sheikh Abdurrahman Ahmad al-Misri. This sheikh, according to Zaini-Lajoubert (2008) and Chambert Loir (2013), influence Abdullah's political thought immensely. According to Chambert-Loir (2009: 56): 
Barangkali beliaulah (Syeikh Abdurrahman) yang memupuk minat Abdullah terhadap ilmu politik, sehingga pada sekitar tahun 1815 Abdullah menulis karangannya yang paling terkenal, iaitu Hikayat Mareskalek.

(Perhaps it was he (Sheikh Abdurrahman) who nurtured Abdullah's interest in politics, so that around 1815, Abdullah wrote his most famous work, Hikayat Mareskalek.)

The books he studied were books of etiquette that had been in existence in the Malay world for a long time. He surely was familiar with at least Taj-us Salatin (1603), the political work in Malay by Bukhari al-Jauhari, which the former had adapted from Nasihat al-Muluk, a "mirror" text or etiquette literature in Persian by al-Ghazali; Bustan al-Salatin (1638) by Nuruddin al-Raniri, which was also heavily influenced by Persian mirror/ etiquette works (Jelani, 2008). Hikayat Mareskalek thus not only transmits Abdullah al-Misri's political vision but also his political thought, which had been very much influenced by these works (Chambert-Loir, 2009).

The structure of this text itself displays several influences from etiquette literature (see Jelani, 2008). Although the title classifies the work as a hikayat, it does not have a plot like a novel. Instead, it conveys piecemeal (though in exact detail) and is loosely connected - linking the irrelevant with stories, anecdotes, memorates and episodes to animate the various aspects of the characters, issues and morals under discussion. Chambert-Loir (2009: 71) gives a good explanation of the structure of this text:

Teks Hikayat Mareskalek tidak terbahagi atas bab atau fasal sehingga terbaca sebagai suatu cerita yang berkesinambungan atau struktur yang jelas, hanya terpotong di sana sini oleh kisah atau petikan sebagai contoh.

(The text of Hikayat Mareskalek is not divided into chapters or sections that can be read as a narrative that has continuity or a clear structure; it is interrupted here and there by tales and excerpts as examples.)

\section{DAENDELS IN HIKAYAT MARESKALEK}

Judging by his lifespan, Abdullah al-Misri would have been witness to several shifts of power among the Europeans, particularly in Indonesia the most significant perhaps being the Dutch-British-Dutch shift that took place between 1811 and 1816 (see Chambert-Loir, 2009). While not a local himself, he would have been very much affected by the actions of the colonial 
powers who oppressed and exploited the local population (see his description in Hikayat Mareskalek pp. 38-46). He is obviously enraged by such actions and curses the "white-skinned people" (p. 46): "Surely Allah will deal as harshly with the white-skinned people as they acted in Java at the time".

While criticizing the actions of the Europeans, he remains in awe of their ability to govern well "and those who ruled the country wisely were the white-skinned people", (Hikayat Mareskalek p. 52) and manipulate the locals "and because of the wise way in which they ruled, even the exploited people were happy" (Hikayat Mareskalek p. 47). He is also in awe of their ability to defeat local kingdoms; Daendels, for example, is able to overpower the sultan of Banten, the sultan of Cirebon and the sultan of Yogyakarta, (see Chambert-Loir, 2009). Abdullah is also not short of praise for the strategies and methods by which the Dutch and British maximize profit gained from the land (see Hikayat Mareskalek, pp. 56-66). At the same time, he turns inward, observing the actions, behaviour and antics of the locals, and being disappointed at their careless attitude "and all the people in Java forget and are careless of the next world" (Hikayat Mareskalek p. 47), their passiveness and "ignorance" (in Hikayat Mareskalek), they are likened to "fruit flies in figs" (see p. 57) to the extent that it makes it easier to exploit them, while their land, sovereignty, and their culture is violated by foreign people (see Hikayat Mareskalek, pp. 47-49).

In his travels from place to place as a merchant (even to Thailand in 1823, and Bali - 1824), he must have also witnessed many of the shortcomings, whims and antics in local politics. In the hikayat he brings such episodes to life as tales by ship captains (see pp. 60-61). Situations of political decay may have led him to write his two "petunjuk kepada raja-raja" (guides from kings) - the abovementioned etiquette/mirror works.

Among the European figures that attracted Abdullah's attention was Maarschalk (Marshal) Daendels, who was made governor of the Dutch Indies in Batavia between1808-1811. Interestingly, he was drawn to write about Daendels and not Raffles, who had been appointed governor of Batavia in 1811, when Abdullah was writing his hikayat, as the British had taken back Batavia from the Dutch at this time. Daendels may have been the more outstanding figure in the minds of the Javanese. In colonial history, Daendels was a controversial figure. Behind all the social, political and economic reforms that he carried out, he often was not seen in a favourable light. Vlekke (in Chambert-Loir, 2009:54) says about him: 
Maka Daendels mulai bekerja dengan membanting korupsi, merombak administrasi, membangunkan jalan dan banteng, pendek kata dengan melakukan segala tindakan yang jelas akan dilakukan oleh seorang yang menamakan diri diktator. Dia menghasilkan banyak, tetapi dibenci dan dimusuhi oleh banyak orang yang dirugikannya; akibatnya penggantinya, iaitu Thomas Stamford Raffles berhasil tampil sebagai orang satu-satunya yang menata kembali pemerintahan di Jawa, sedangkan citra Daendels tercemar oleh aspek buruk perombakan tersebut.

(Thus Daendels began to battle corruption, reshuffling the administration, building roads and forts, in short he did everything that clearly would be done by someone who considered himself a dictator. He achieved much but was hated and opposed by many of those he had aggrieved; as a result, his successor, Thomas Stamford Raffles, managed to emerge as the one person able to reorganize the administration of Java, while Daendels' image was marred by the negative aspects of his reforms.)

Daendels is seen by local historians as a stern and unfeeling European administrator. According to Chambert-Loir (2009: 66), among the inhabitants of Java, he was known as "Marsekal Besi" (Iron Marshal), and often called "Gubernor Jendral Guntur" (The Thunder Governor-General"), while the Sundanese created a word play on his title, calling him "Mas Galak" (Brother Fierce).

Abdullah al-Misri was also acutely aware of how the locals perceived Daendels. In Hikayat Mareskalek, these perceptions are shown through the voice of one of the locals, according to whom just the very mention of the name "Daendels" is chilling (p. 57):

Apalah gunanya perpayah susah, habis belanja Tuanku mengerjakan pulau ini, siapalah seteru yang berani datang ke tanah Jawa negeri yang besar dan kaya lagi makmur, manusia beribu-ribu laksa, maka sekarang Tuan Besar yang kuasa memerintah jagat dunia Jawa terlebih lagi takut segala manusia menengar nama Tuan yang maha mulia dan maha besar kuasa gagah berani memerintah dunia.

(What use is all this effort - My Lord has spent everything to develop this island, and which enemy dared come to this land of Java, as large, wealthy and prosperous as it is, with its hundreds of thousands of inhabitants; but now the powerful Master rules all of Java, and all of mankind are fearful upon hearing the name of this most honourable, most powerful, and most courageous Master, the ruler of the world.) 
When reproached by Daendels, they hang their heads quietly and merely admit their own ignorance and weakness; as can be found on page 50 of the text: "Sir, you have more knowledge than all those who are knowledgeable", or when they acquiesce, as on page 61: "and all the ship captains kept silent, knowing their king was stupid".

From Abdullah's point of view, Daendels has unusual characteristics that can be used to illustrate several political traits and practices of rulers that are in line with his own political thought. Just as previous authors of etiquette literature had selected good and bad examples from Islamic figures (the Prophets, companions, religious scholars) Muslim and non-Muslim kings and the like. Abdullah chooses Mareskalek to concretize the moral arguments of his political thought. Following the structure of etiquette literature, the actions and principles of Mareskalek are backed up with Qur'anic verses, hadith (sayings of the Prophet) and sayings of religious scholars. ${ }^{16}$ One example of an argument structured in this way can be seen on page 59. Here, Abdullah wishes to convey the idea of justice, and begins putting forth this idea using Mareskalek as his mouthpiece:

“... tiada boleh ramai negeri itu melainkan dengan adil sultan itu memerintah kerajaan negerinya ...”

(“... a country will not be well-populated unless its sultan rules his kingdom justly ...”)

This idea is then strengthened with:

(a) a hadith of the Prophet.

(b) a second hadith of the Prophet.

(c) an excerpt of the sayings of Sultan Abd al-Malik ibn Marwan.

(d) a third hadith of the Prophet.

It is of no issue to him that Mareskalek is not a Muslim. To justify this, Abdullah quotes this purported hadith by the Prophet: "The most beloved of all people includes four unbelievers, firstly, King Nushirwan for his justness, and Hatim al-Tai for his generosity, and Imru al-Qais for his wisdom and eloquence, and Abu Talib for his excessive goodness".

Daendels's arrogance, boorishness and rudeness are also not viewed negatively by Abdullah, or as tarnishing the character in any way as he views these as typically European characteristics that are part and parcel of 
the colonial culture, and their race. He pays more attention to Daendels's "wisdom" in ruling the country and the local populace: "and those who ruled the country wisely were the white-skinned people" (p. 52). This is shown through Daendels's actions, as he brings about development and prosperity (through the building of roads, increasing the number of people, and developing the rural economy, for example) to the people, which, according to Abdullah, the local rulers failed to achieve due to their own weaknesses.

Wisdom is equated with Europeans - intelligent people (p. 48). A closer view of the text shows this to be contrasted with the characteristics and situation of the locals who are seen by him as stupid, brainless or lacking insight (p. 47). Interestingly, Abdullah does not see such characteristics as being intrinsic to the local people (unlike Abdullah Munshi, in Kisah Pelayaran Abdullah ke Kelantan, see Noriah, 2007). To him, such characteristics are the result of certain personal weaknesses that have "killed off" their ability to think. He says: "the moment something new was introduced to his mind, it would be killed off by all those things (weaknesses)" (p. 53). "All those things" are: avarice (thus forgetting the hereafter) and "beguiled like ants by the sweetness of sugar, tricked like a pigeon through cooing" (p. 48.); women "surrounded by women day and night"; pastimes - gambling, hunting; wasting time: "walking here and there"; and sloth (sleeping a lot).

Both the local people and their king often show their stupidity through various actions and opinions, causing them to be labelled "stupid" by the colonizers and even their own people. At times, comments on their stupidity are put into the mouth of Mareskalek: "You are so stupid, you're like a sleeper trying to teach me, the waking person who is smarter than you" (p. 54) or:

tiada berguna orang beribu-ribu itu kalau bodoh seperti lu sekalian ... Seperti kerbau lu sekalian, gua suruh pikul kayu batu daripada akal gua terlebih besar daripada lu segala yang bodoh.

(even if there were thousands of idiots like all of you they would be of no use ... You're all like buffaloes, fit only to carry wood and stones at my bidding, because I have more brains than you idiots put together") (p. 58).

Even the locals themselves admit to this at times: "Master, a thousand apologies, do not take offence at our stupidity ..." (p. 61); "and all the ship captains kept silent, knowing their king was stupid" (p. 61).

However, Abdullah also does not present such intelligence as a completely positive characteristic. It is an asset but when it is used for deception and 
fraud, especially in this case when the result is the exploitation of the local people, it becomes a blameworthy characteristic. In this hikayat, intelligence in this second sense is associated with the cunning and deceit of the Europeans in hoodwinking, cheating, and manipulating the colonized peoples and to get the most out of the colony's natural resources in order to maximize their own profit. In the words of Abdullah: "every single day is spent thinking how to get money from the coffers of those people into the Company's storehouses" (p. 43); further, the intelligence to find ways and means to exploit the locals: "thus all the traders ... were squeezed like one squeezes coconuts for their milk, leaving only the pulp, then only will the squeezing stop" (p.43). Sometimes, because of the cunning of the Europeans, the exploitation of the locals happened without their noticing it, as it was in the form of burdensome taxes, duties and leases (see pp.43-47).

Thus, before bringing Daendels into the narrative space as an intelligent administrator, Abdullah uses up 24 pages to explain and illustrate the "intelligence" of the Europeans - the British and the Dutch - in both its positive and negative ways. Only after an entire chapter on the antics of the colonizers is Mareskalek brought in to thicken the plot. Before focusing on his characterization, Mareskalek is introduced in these few words: "For truly Mareskalek had great intelligence, much knowledge and great courage" (p. 56). Based on such details of his character, Mareskalek seems to be the embodiment of precisely that image of Europeans that Abdullah presents in the earlier 24 pages.

Apart from depicting his personality as what is to Abdullah the typical colonizer - stern, arrogant, boorish and rude (insulting the king and the locals), Abdullah uses and in fact manipulates this character by embellishing stories about him to realize his political message. This can be seen in Hikayat Mareskalek whereby the writer uses several stories or anecdotes to illustrate his political thought. Some of these stories about the character are based on fact while others are perhaps based on rumours circulating among the local populace, or are merely invented by the writer himself. These anecdotes are employed to depict the character's traits, behaviour and method of administration which the writer feels should serve as examples for the local kings. These episodes include:

(a) The episode at the foot of Mount Megamendung: This episode is included to highlight the character's plans for development (programmes to "improve Java" (p. 50), including the rapid development of agriculture (rice, coffee, 
coconut, areca and nuts), social welfare programmes (better housing and roads) and statebuilding (increasing the population). The aim of such development is explained by Abdullah through Daendels:

“... apabila ada negeri itu ramai bagus rupanya dan rumah dan jalannya dan banyak makanan, maka segala orang itu menaruh cinta hati hendak datang ke mari, maka tiadalah jadi besar negeri itu kalau tiada perahu dagang datang ke negeri itu."

(“...when the state is well-populated it looks attractive, and with its houses and roads and plentiful food, people will want to come here, and no country will prosper if no trading ships go there.") (p. 50)

In this episode, too, Abdullah attempts to criticize Islamic religious scholars kiai (Islamic religious teachers) and santri (students of Islam) who avoid doing "rough" work - "carry the burden of governing the state" (p. 51) as they feel that their sole responsibility is reading the Qur'an, fasting and prayer. Mareskalek attacks such thinking as going against the principle of "welfare for the people" that does not exclude anyone - Abdullah's political message at the end of this episode is that "the ignorant and those with religious knowledge, the sick and the strong ... the fearful and the brave - all are equally of use to the king" (p. 51).

(b) The tale of Bang Selamat is an interesting episode that illustrates Abdullah's idea about the characteristics and power of kings:

Ada seorang gunung (namanya Bang Selamat) terlalu banyak kebaktiannya kepada general Mareskalek ... dikaruniai nama Pangeran Negara dan dikaruniai alat kerajaan tinggi panjang dua hasta lebar tiga jengkal, bertombak panjang tiga depa, dan payung besar kiri kanan dan dikaruniai pula pakaian busana prabon bercepiau, pakaian kerajaan Sang Ratu.

(A man from the mountains (named Bang Selamat) was of much service to general Mareskalek ... he was awarded the title Pangeran Negara and regalia: a sceptre two cubits long and three spans wide; a spear three armspans long; two large parasols, for left and right; and a suit of good clothing with a headcover as is worn in the court of the ruler.) (p. 54).

This appointment is opposed by the nobility, among them the son of the sultan of Cirebon, who says: 
... dari itu orang gunung Bapa Selamat itu tiada patut sekali-kali Tuan angkatkan Pangeran karena bukannya ia asal anak priyai ... jika Tuan namakan lurah atau kliwon patut...

(... a man from the mountains such as Bapa Selamat should never be made a Pangeran because he is not of noble blood ... it would be more suitable to make him a headman or even a kliwon...)

Mareskalek then makes fun of the prince of Cirebon (by pointing out the prince's own humble background (p. 55), saying, "And those who are now princes and sultans and kings, they are all people of this world, none has come down from heaven." Mareskalek then refers to:

... kitab agama yang diturunkan kepada para anbiya: Maka di dalam dunia ini, siapa yang Tuan Allah suka menjadikan Sultan dan Pangeran dan Yang Dipertuan, maka orang itulah kita turut perintah ...

(... the scriptures that were revealed to the Prophets: that in this world, whomever Allah raises to be a sultan or a prince or a ruler, we should obey him...)

Through Daendels, Abdullah presents an Islamic idea of kingship, which he then supports with this quote, Surah al-Mulk:

Wahai Tuhan yang mempunyai kerajaan, Engkau beri kerajaan kepada orang yang engkau kehendaki dan Engkau cabut kerajaan dari orang yang Engkau kehendaki. Engkau muliakan orang yang Engkau kehendaki dan Engkau hinakan orang yang Engkau kehendaki ...

(O Allah, Owner of Sovereignty, You give sovereignty to whom You will and You take sovereignty away from whom You will. You honour whom You will and You humble whom You will ...) (p. 55).

Abdullah then summarizes, through his character Mareskalek that:

Maka nyatalah kehendak Allah Bapa Selamat, orang Gunung, jadi Pangeran dan lu anak-anak Sultan Cirebon ... sekarang jadi bodoh diperintah oleh Bapa Selamat, inilah kodrat iradat Allah taala.

(It is clearly the Will of Allah that Bapa Selamat, a man from the mountains, is to be a Pangeran and you, the sons of the Sultan of Cirebon ... are now 
the idiots ruled by Bapa Selamat, this is the Power and Wish of Allah Most High) (p. 56).

The nonsensical belief that kings are divinely descended is also attacked by Abdullah as something illogical that is recorded in ancient Javanese literature (perhaps the Panji stories and the Ramayana epic), such as the idea that the kings are capable of reincarnation:

maka telah masyhur ke tanah Melayu perang raja-raja di tanah Jawa zaman dahulu-dahulu itu, mati di dalam peperangan hidup pula kembali, perang lagi.

(it is a tale that has spread to the Malay lands that the kings of Java who died in ancient battles came back to life to continue fighting in battle.)

Says Abdullah: "I went all over Java - east, west, north and south - and never once came across such a thing" (p. 56). Mareskalek is again used as an example here: "even Mareskalek has not died in battle and been reborn" (such as is believed to happen to the Malay kings). At the end, Abdullah inserts a lesson from Islam: "every living thing must die" (p. 56).

(c) The episode of Mareskalek's dialogue with the ship captains: this episode includes a memorate by the ship captains concerning the "kelaku-perangai" (behaviour) of the kings of several kingdoms they had been to. This episode supports Abdullah's views concerning the weaknesses of the Malay kings: that they are of low character, indifferent to their people, pleasure-seeking, and too much ruled by their wives. Mareskalek is used as a mouthpiece to speak about the true source of these weaknesses, and according to him the weaknesses of the Malay kings is that they are appointed because of their ancestry and not because of their intelligence. Abdullah, through the words of Mareskalek, warns: "and this is the greatest way to bring doom to the lands of the dark-skinned people..." (p. 61). Abdullah then divides kings into two types: kings who rule - who seek to increase the population and improve the kingdom and enrich its coffers; and kings who are custodians of a kingdom - "for whatever they inherit from their elders does not increase" (p. 61).

Through the above anecdotes, Abdullah stresses his political message, as an example and a lesson for kings. It appears that the stories concerning 
Mareskalek (both historical and fictitious ones) are used or manipulated for the moral that can be gleaned from them. In this hikayat, Mareskalek becomes significant not because of his own doings as a colonial administrator but as an example, fulfilling Abdullah al-Misri's political vision.

Through the words of Mareskalek, Abdullah also directly expresses his own political thought. Mareskalek is said to lecture on friends and enemies, and about the mind and desire (p. 50); he is said refer to the Bible (p. 57) and talks about the personalities and contributions of ancient figures - David, Alexander the Great, Aristotle, the Vizier of King Nushirwan the Just; and the concept of the "power" of rulers which he backs up with Qur'anic verses (p. 55). Through Mareskalek, too, Abdullah puts forth the Islamic political idea of electing a king. Islam views the power to rule as a mandate and responsibility from God, given to those He chooses. This idea is supported by a direct quotation from Surah Ali-Imran (3:26), which can be translated to mean: “... You give sovereignty to whom You will and You take sovereignty away from whom You will. You honour whom You will and You humble whom You will ...".

Abdullah also touches on the Islamic idea concerning the role of fate in human lives at this point (p. 56). The idea about how fate affects human destiny is expressed in the episode about Bang Selamat's appointment as a pangeran (noble) by Mareskalek, even as this appointment upsets a prince of the sultan of Cirebon. Mareskalek rationalizes this by saying, " ... this is the Power and Wish of Allah Most High".

Mareskalek is also employed by Abdullah to voice ideas from Islamic political philosophy, about the concept of transience of all earthly power. When Daendels is removed from his position, Abdullah uses the "wheel metaphor" to illustrate the "rise and fall" of a ruler. The metaphor is expressed through the words of Janssen - the officer who replaces Daendels: "life in this world is like the (wheels of a) car, it has its ups and downs" (p. 67).

In this hikayat, Abdullah not only presents Mareskalek as a worldly-wise Dutchman but also as one who is knowledgeable about Islamic history, the Bible, the Qur'an, and the hadith of the Prophet, capable of quoting from these to strengthen his arguments and support his actions. Abdullah says "Mareskalek was thoroughly knowledgeable in all scripture" (p. 70), what is more interesting, though, is that he is described as being able to play the flute and compose ballads in French; his ballads convey detailed advice about friends and enemies, about the importance of a ruler's justness in helping his kingdom to grow and prosper. Once again, Mareskalek is the mouthpiece 
for Abdullah's political ideas for at the end of the ballad, Abdullah inserts an overt political message using words quoted from Sultan Abd al-Malik ibn Marwan (p. 59):

binasa negeri raja-raja itu dengan sebab dua pekerjaan. Maka yang satu daripada dua itu, lemah raja itu mendirikan hukum adat perintah dalam negerinya, dan kedua sebab sangat keras aniaya raja itu, maka dengan dua sifat itu tiada boleh jadi raja.

(the kingdoms of kings are destroyed through two things. The first being that the king is weak in implementing law and order in his kingdom, and the second that he is oppressive and cruel, and both these characteristics make one unsuitable to be king.)

At the end of the hikayat, the writer gives Mareskalek's character a drastic twist. This fearsome character with his "invincible" image is softened. The depiction is surprising. He is shown to shrink before, even obey, Susuhunan Kalijaga, who appears twice in his dreams. In the first dreams, he reprimands Mareskalek for calling himself "Susuhunan", while in the second time he warns Mareskalek and prophesies the latter's downfall.

Waking from his dream, Abdullah depicts the character in the following way (p. 62): "Mareskalek startled from sleep, and awakened with fear; his face pale and his body weak". After this incident, Mareskalek is shown to have become a different person. His first action is to remove the title "Susuhunan Kangjeng Kangsinuhun Mangkurat Mangkubuwana" that he had enjoyed. He says (p. 64): "I do not wish that people call me Susuhunan"; next, he visits the mausoleums, mosques and palaces of the Wali Songo (nine holy men) in Cirebon and Gerisik; there he prostrates himself in the mosque, gives alms to the poor, and invites people to read Qur'an and hold feasts of remembrance at the palaces of the Wali Songo. This, we feel, is presented as a lesson for him in return for his impertinence towards the local culture, kings and people.

In these "spiritual" journeys, Daendels realizes his own insignificance after witnessing the greatness of the Wali Songo, for example, upon seeing the marks where the staff of Susuhunan Kalijaga split Mount Renggat Telaga Urang. After this, Mareskalek is depicted as bearing a great emotional burden, which Abdullah expresses in the following way: "and he returned to Batavia by ship, feeling depressed, having lost half his mind" (p. 65). 
After this incident, which may be simply a figment of the writer's imagination, Daendels is presented as being more caring towards the locals. This is shown through several episodes: firstly, through the creation of a battle square at Pasar Senin, which, as Daendels explains, is created for the following reason (p. 65): "if the enemy comes, do not fight them inland so that the common people are safe and will not be killed". He then also instructs that scientific methods are used to calculate the direction of prayer for the mosque.

Through these dreams, which surely were invented by the writer, Abdullah teaches these figures and the other Malay rulers to "realize" that the existence of a higher power that determines their future, and he teaches them to respect local morals, beliefs and practices. Thus, Abdullah turns the arrogant and boorish Mareskalek into a leader who realizes his own insignificance. The next episode is inserted to further soften the character: on his return, he dreams once again of Susuhunan Kalijaga, who tells him, "O Mareskalek, the bird that flies on high must in the end descend, and the sun up high will also come down some time, never to rise again" (p. 73).

This dream foreshadows the fall of Mareskalek and is inserted by the writer to remind readers of the "transience" of power in this world and of life; the author quotes from the Qur'an to buttress this point "... and You take sovereignty away from whom You will” (Surah Ali-Imran, 3:26).

Abdullah of course knows what happened to Mareskalek in Batavia. This hikayat was written after his fall, in fact, after the time of the Dutch in Java. Therefore, this dream is only inserted as a warning for the Malay rulers about power and authority. Not long after the episode of this dream, Abdullah talks about the political change in Europe that leads to the curt dismissal of Mareskalek by his successor. This event - the dismissal of Mareskalek - also shows Allah's retribution for rulers who exceed their limitations (just as the stories of oppressive Malay rulers of the past were included in other historical and etiquette literature). Abdullah also does not display any sympathy for this character. About Mareskalek being told to resign, the author writes:

Maka diam Mareskalek, hilang akalnya, jadi bodoh, lalu memulangkan anak kunci kerajaan dan kebesaran tanah Jawa ... dan menyerahkan buku negeri syarah bayan al-akbar, menyatakan peruntungan Kompeni ... Maka Mareskalek pun turun ke kapal bagaimana datangnya begitu juga perginya. (Mareskalek became quiet, having lost all sense, like an idiot, and handed over the instruments of government and power over Java ... and the books 
in which the earnings of the Company were recorded ... and went down to the ship, going back the way that he had come) (pp.66-67).

As in other episodes of Mareskalek's life that Abdullah presents, even the fall of Mareskalek is used by Abdullah in his hikayat to make a point, in this case that in every government there should be a system of "checks and balances". That which is excessive should be controlled or limited, for power is not eternal. Abdullah uses the sea as a metaphor to put forward his idea: "the tide must ebb, if the tide were high forever, this world would drown" (p. 66).

Daendels's departure, “... going back the way that he had come", illustrates how arbitrary all forms of power and how insignificant human beings are, once their power is taken back by Allah - a pointed moral message at the end of a work of etiquette literature.

\section{CONCLUSION}

Hikayat Mareskalek depicts the stern Daendels "softened" at the end, rounding out his character to represent the kind of leader who embodies Abdullah's political ideal. The writer does this to round off the personality of his character, Mareskalek, so that he may stand as an example to be followed. In order to fulfil his political vision, Abdullah uses historical events but fills in the history with scenes and episodes that are probably fictitious, or legend and rumour. In this text, just as in many other etiquette literature, fact and fiction is combined to bring forth a work that is at once both the political and moral vision of its writer.

In this work, the character chosen is Daendels (from among the colonial personalities), as well as anecdotes and rumours or legends about him, while his character is rounded out to present Abdullah's idea of the etiquette of a ruler. The aim is to make Daendels - his political ideas and economic strategies - an example that should be followed, while being uncouth and stern should be avoided by the local rulers who are referred to as "orang sebelah sini" (the people from this side) or "orang kulit hitam" (lit.: the black-skinned people, here "the dark-skinned people").

Abdullah's work is not meant to record colonial history or feature a colonial character but is meant to employ history and certain figures to put forward his political thought, his ideas concerning what a true Muslim leader should be like. Based on this, Hikayat Mareskalek is etiquette literature or a "mirror" for the Malay rulers in the same vein as other etiquette literature 


\section{such as Taj-us Salatin and Bustan al-Salatin, which were written over a century earlier.}

\section{NOTES}

1. For further discussion of this, refer to Noriah Taslim, "Kolonialisme dan Fenomena Sastera Abad Peralihan" (forthcoming, ATMA).

2. For a discussion of the "old" type of writing, see Noriah Taslim, Gema Tradisi: Suara dan Minda, (forthcoming, Dewan Bahasa Pustaka, Brunei Darussalam).

3. Outside the palace, with the exception of a few writers such as Sultan Mahmud Badaruddin in Palembang and a group of aristocratic writers in Riau; see also Ras, 1985.

4 Skinner [1963] terms them "non-aristocratic artists".

5. For example, La'udin, Ahmad Rijaluddin, Abdullah Munshi, Abdullah al-Misri.

6. Sweeney's term (2008): "Malay literature of the European courts".

7. In many cases also to be given a royal appointment, such as the writing of Hikayat Raja Siam by Abdullah al-Misri and for political asylum, as was the case with Lau'din in Bencoolen.

8. Marco Polo's notes on his travels to Sumatra in the 1290 s, followed by a number of other travellers. See A. Reid, 1995.

9. See Raimy Che-Ross, 2003; and for the analysis of it as a travelogue see Noriah Taslim, 2010.

10. This is an important in order to differentiate biography such as was introduced through the coming of Islam in the mid-16th/17th centuries and are considered "adaptations" or Islamic literature in Malay; these texts concern the lives of the Prophets, such as Qisas al-Anbiya. Unlike the European type of biography/memoir, these texts did not inspire local people to write biographies/narratives about themselves.

11. Hikamat was a Batak from the highlands of Sumatra, a boy who was rescued from slavery by Keasberry and educated by him at the mission school in Mount Zion, Singapore. This text is his life story, beginning form his time as a slave through the time of his emancipation and as Keasberry's pupil, and his eventual conversion to Christianity; the text also tells about his escape from Sumatra to Singapore and his experiences at Keasberry's Mission School.

12. Except Syair Perang Betawi, 1811, written in praise of the role of Raffles in the British attack on the Dutch in Batavia and Syair Hemop atau Syair Kompeni Welanda berperang dengan Cina, in which van Imhoff is eulogized for his heroism.

13. Nevertheless, for his own survival, he was forced to seek the patronage of the Dutch in Batavia; Hikayat Siam (1823), for example, was written for van der Capellen, the Dutch Governor-General of Batavia, see Chambert-Loir, 2009.

14. See. Jelani Harun, 2008 for a discussion of this genre and its features.

15. Bustan al-Salatin was written by Nuruddin al-Raniri for Sultan Iskandar Thani of Acheh (1631-1641).

16. See Jelani Harun, 2008, concerning the structure of etiquette literature. 


\section{REFERENCES}

Chambert-Loir, Henri, 2009. "Abdullah al-Misri, Penulis Sebuah Teori Politik di Jawa pada Awal Abad Ke-19" in Kembara Bahari: Esei Kehormatan 80 tahun Adrian B. Lapian. Jakarta: Komunitas Bambu.

Jelani Harun, 2008. Bustan al-Salatin. A Malay Mirror for Rulers. P. Pinang: Penerbit Universiti Sains Malaysia.

Kathirithamby-Wells, J., “A Note on Malay Historical Writing in Benkulin During the British Era" in Indonesian Circle, no. 22, 1980.

Muhammad Yusoff Hashim 1991. Terengganu Darul Iman. Tradisi Pensejarahan Malaysia. Kuala Lumpur: Dewan Bahasa dan Pustaka.

Murtagh, Ben 2014. "Syair Inggeris Menyerang Kota: Some Preliminary Remarks", in Jelani Harun \& Ben Murtagh (eds.). Mengharungi Laut Sastera Melayu. Kuala Lumpur: Dewan Bahasa dan Pustaka

Noriah Taslim, "From Ethnocentrism to Eurocentrism: Positioning Abdullah Munshi's Discourse on the Malays" in Malay Literature 20, 2007.

Noriah Taslim, "Syair Peri Tuan Raffles Pergi ke Minangkabau: A Preliminary Reading of an Early 19th Century Tavelogue" in Malay Literature 23:2, 2010.

Noriah Taslim (n.d.). Hikayat Nakhoda Muda: Sebuah Biografi Melayu Abad ke-18. (forthcoming) Kuala Lumpur: Yayasan Karyawan

Noriah Taslim. "Kolonialisme dan Literary Renaissance pada Abad Transisi". Focus essay" in Dewan Sastera April, 2015.

Noriah Taslim (n.d.). Kolonialisme dan Sastera Melayu Abad Peralihan (forthcoming) ATMA, Universiti Kebangsaan Malaysia.

Noriah Taslim (n.d.). Gema Tradisi: Suara dan Minda (forthcoming) Brunei Darussalam: Dewan Bahasa dan Pustaka.

Parnickel, Boris 1995. Perkembangan Sastera Nusantara Serumpun (Abad ke-7ke-19). Kuala Lumpur: Dewan Bahasa dan Pustaka.

Raimy Che-Ross, "Syair Peri Tuan Raffles Pergi ke Minangkabau: A Malay account of Raffles' second expedition to the Sumatran highlands in 1818" in JMBRAS LXXVI:2, 2003.

Raimy Che-Ross, "Hikayat Hikamat: The Malay memoirs of a Sumatran Christian" in JMBRAS 80:1, 2007.

Ras, J.J. 1985, "Review of the Hikayat Perintah Negeri Benggala" in Journal of Southeast Asian Studies 16, 1985.

Reid, Anthony, 1995. Witnesses to Sumatera. A traveller's Anthology. New York: OUP. Salmon, Caludine, 1999. "Bengal as Reflected in Two South-east Asian Travelogues from the Early Nineteenth Century" in Denys Lombard et al. (eds.). Commerce and Culture in the Bay of Bengal, 1500-1800. New Delhi: Manohar.

Skinner, C., "Transitional Malay literature: Part I, Ahmad Rijaluddin and Munshi Abdullah" in BKI 134:iv, 1978. 
MALAY LITERATURE VOLUME 29 NUMBER 12016

Skinner. C., 1982. Ahmad Rijaluddin's Hikayat Perintah Negeri Benggala. The Hague Nijhoff: BTLV 22.

Sweeney, Amin 2005. Karya Lengkap Abdullah bin Abdul Kadir Munsyi. Jilid 1. Jakarta: Kepustakaan Popular Gramedia.

Sweeney, Amin 2008. Karya Lengkap Abdullah bin Abdul Kadir Munsyi. Jilid 3. Jakarta: Kepustakaan Popular Gramedia.

Tiwon, Sylvia 1999. Breaking the Spell. Colonialism and Literary Renaissance in Indonesia. Leiden: Department of Languages and Cultures of South-east Asia and Oceania.

Zaini-Lajoubert, Monique 2008. Karya Lengkap Abdullah bin Muhammad al-Misri. Jakarta: Penerbit Angkasa/Ecole francaise d'Extreme-Orient. 


\section{The Excerpts from Hikayat Mareskalek Listed Below are Discussed in this Article}

\begin{tabular}{|c|c|c|c|}
\hline No. & Page & Hikayat Mareskalek & English Translation \\
\hline 1. & 18 & "berjalan kaki wira-wiri" & "walking here and there" \\
\hline 2. & 34 & $\begin{array}{l}\text { "bercampur dengan perempuan siang } \\
\text { malam" }\end{array}$ & "surrounded by women day and night" \\
\hline 3. & 43 & $\begin{array}{l}\text { "maka setiap-tiap hari itu mencari } \\
\text { pikir yang boleh masuk berial-rial dari } \\
\text { peti orang itu masuk ke dalam gudang } \\
\text { Kompeni" }\end{array}$ & $\begin{array}{l}\text { "every single day is spent thinking how } \\
\text { to get money from the coffers of those } \\
\text { people into the Company's storehouses" }\end{array}$ \\
\hline 4. & 43 & $\begin{array}{l}\text { "maka jadilah segala orang yang } \\
\text { berniaga itu ... diperahnya seperti } \\
\text { orang yang mengeluarkan santan } \\
\text { daripada kelapa, tinggal hampasnya } \\
\text { tiada bersantan lagi, baharu ia berhenti } \\
\text { memerah" }\end{array}$ & $\begin{array}{l}\text { "thus all the traders ... were squeezed } \\
\text { like one squeezes coconuts for their milk, } \\
\text { leaving only the pulp, then only will the } \\
\text { squeezing stop" }\end{array}$ \\
\hline 5. & 46 & “orang kulit putih” & "white-skinned people) \\
\hline 6. & & $\begin{array}{l}\text { "Maka sesungguhnya perintah Allah } \\
\text { kerasnya Allah taala itu di atas orang } \\
\text { kulit putih yang di tanah Jawa berlaku } \\
\text { pada masa itu" }\end{array}$ & $\begin{array}{l}\text { "Surely Allah will deal as harshly with the } \\
\text { white-skinned people as they acted in Java } \\
\text { at the time" }\end{array}$ \\
\hline 7. & 47 & $\begin{array}{l}\text { "maka daripada bijaksana orang kulit } \\
\text { putih memerintah, maka suka juga } \\
\text { segala orang yang rugi itu," }\end{array}$ & $\begin{array}{l}\text { "and because of the wise way in which } \\
\text { they ruled, even the exploited people were } \\
\text { happy" }\end{array}$ \\
\hline 8. & 47 & $\begin{array}{l}\text { "Maka segala orang yang ada di tanah } \\
\text { Jawa itu lupa dan lalai akhirat," }\end{array}$ & $\begin{array}{l}\text { "And all the people in Java forget and are } \\
\text { careless of the next world" }\end{array}$ \\
\hline 9. & 47 & tidak berakal & "brainless" \\
\hline 10. & 47 & tidak mempunyai mata hati & "lacking insight" \\
\hline 11. & 48 & orang yang banyal akal & "intelligent people" \\
\hline 12. & 48 & "Segala hal" & "all those things" \\
\hline 13. & 48 & $\begin{array}{l}\text { "terpedaya seperti semut dengan gula } \\
\text { yang manis, seperti terpedaya burung } \\
\text { punai dengan dekut" }\end{array}$ & $\begin{array}{l}\text { "beguiled like ants by the sweetness } \\
\text { of sugar, tricked like a pigeon through } \\
\text { cooing" }\end{array}$ \\
\hline 14. & 50 & "membaiki tanah Jawa" & "improve Java" \\
\hline 15. & 50 & $\begin{array}{l}\text { "Tuan besar juga yang terlebih mengerti } \\
\text { daripada segala orang yang mengerti" }\end{array}$ & $\begin{array}{l}\text { "Sir, you have more knowledge than all } \\
\text { those who are knowledgeable" }\end{array}$ \\
\hline 16. & 51 & "memikul kerajaan negeri" & "carry the burden of governing the state" \\
\hline 17. & 51 & $\begin{array}{l}\text { "bodoh dan alim, dan sakit dan kuat ... } \\
\text { penakut dan berani, maka sekalian itu } \\
\text { berguna kepada raja-raja" }\end{array}$ & $\begin{array}{l}\text { "the ignorant and those with religious } \\
\text { knowledge, the sick and the strong ... the } \\
\text { fearful and the brave-all are equally of } \\
\text { use to the king" }\end{array}$ \\
\hline
\end{tabular}


MALAY LITERATURE VOLUME 29 NUMBER 12016

\begin{tabular}{|c|c|c|c|}
\hline No. & Page & Hikayat Mareskalek & English Translation \\
\hline 18. & 52 & $\begin{array}{l}\text { "maka yang bijaksana memerintah } \\
\text { negeri itu bangsa orang kulit putih," }\end{array}$ & $\begin{array}{l}\text { "and those who ruled the country wisely } \\
\text { were the white-skinned people" }\end{array}$ \\
\hline 19. & 52 & $\begin{array}{l}\text { "maka bijaksana memerintah negeri itu } \\
\text { bangsa orang kulit putih" }\end{array}$ & $\begin{array}{l}\text { "and those who ruled the country wisely } \\
\text { were the white-skinned people" }\end{array}$ \\
\hline 20. & 53 & $\begin{array}{l}\text { "maka segera-segera baharu hendak } \\
\text { tambah akalnya maka dibunuh oleh } \\
\text { segala hal (kelemahan) tersebut" }\end{array}$ & $\begin{array}{l}\text { "the moment something new was } \\
\text { introduced to his mind, it would be killed } \\
\text { off by all those things (weaknesses)" }\end{array}$ \\
\hline 21. & 54 & $\begin{array}{l}\text { "Lu terlalu bodoh, orang tidur mau } \\
\text { mengajar sama gua orang jaga lagi } \\
\text { cerdik" }\end{array}$ & $\begin{array}{l}\text { "You are so stupid, you're like a sleeper } \\
\text { trying to teach me, the waking person who } \\
\text { is smarter than you" }\end{array}$ \\
\hline 22. & 55 & $\begin{array}{l}\text { "Maka yang bernama Pangeran } \\
\text { dan Sultan dan Ratu sekaliannya itu } \\
\text { orang dunia ini bukannya yang dikata } \\
\text { Pangeran itu turunnya dari langit." }\end{array}$ & $\begin{array}{l}\text { "And those who are now princes and } \\
\text { Sultans and Kings, they are all people of } \\
\text { this world, none has come down from } \\
\text { heaven." }\end{array}$ \\
\hline 23. & 56 & $\begin{array}{l}\text { "Maka sungguh Mareskalek itu sangat } \\
\text { akalnya dan banyak ilmunya dan gagah } \\
\text { beraninya" }\end{array}$ & $\begin{array}{l}\text { "For truly Mareskalek had great } \\
\text { intelligence, much knowledge and great } \\
\text { courage" }\end{array}$ \\
\hline 24. & 56 & $\begin{array}{l}\text { "Maka aku jalankan tanah Jawa itu } \\
\text { wetan, kulon, lor, kidul maka tiada } \\
\text { kabar seperti itu yang dilihat" }\end{array}$ & $\begin{array}{l}\text { "I went all over Java- east, west, north } \\
\text { and south-and never once came across } \\
\text { such a thing") }\end{array}$ \\
\hline 25. & 56 & $\begin{array}{l}\text { "belum lagi Mareskalek itu mati di } \\
\text { dalam peperangannya hidup pula } \\
\text { kembali" }\end{array}$ & $\begin{array}{l}\text { "even Mareskalek has not died in battle } \\
\text { and been reborn" }\end{array}$ \\
\hline 26. & 56 & : "tiap-tiap yang hidup itu mati" & "every living thing must die" \\
\hline 27. & 56 & $\begin{array}{l}\text { “... inilah kodrat iradat Tuan Allah } \\
\text { taala." }\end{array}$ & $\begin{array}{l}\text { "...this is the Power and Wish of Allah } \\
\text { Most High" }\end{array}$ \\
\hline 28. & 57 & "binatang bari-bari dalam buah ara" & "fruit flies in figs" \\
\hline 29. & 61 & $\begin{array}{l}\text { "maka berdiam segala nakhoda- } \\
\text { nakhoda, diketahuinya rajanya itu } \\
\text { bodoh" }\end{array}$ & $\begin{array}{l}\text { "and all the ship captains kept silent, } \\
\text { knowing their king was stupid" }\end{array}$ \\
\hline 30. & 61 & $\begin{array}{l}\text { "Tuan Besar, ampuni beribu-ribu } \\
\text { ampun, jangan ambil pergusar } \\
\text { daripada bodoh gua sekalian..." }\end{array}$ & $\begin{array}{l}\text { "Master, a thousand apologies, do not take } \\
\text { offence at our stupidity...") }\end{array}$ \\
\hline 31. & 61 & $\begin{array}{l}\text { "maka berdiam segala nakhoda- } \\
\text { nakhoda diketahuinya rajanya itu } \\
\text { bodoh" }\end{array}$ & $\begin{array}{l}\text { "and all the ship captains kept silent, } \\
\text { knowing their king was stupid") }\end{array}$ \\
\hline 32. & 61 & $\begin{array}{l}\text { "maka itulah suatu jalan yang besar } \\
\text { membinasakan negeri orang kulit } \\
\text { hitam..." }\end{array}$ & $\begin{array}{l}\text { "and this is the greatest way to bring } \\
\text { doom to the lands of the dark-skinned } \\
\text { people..." }\end{array}$ \\
\hline 33. & 61 & $\begin{array}{l}\text { "maka barang yang sudah ada } \\
\text { daripada orang tuha-tuhanya itu juga } \\
\text { tiada bertambah" }\end{array}$ & $\begin{array}{l}\text { "for whatever they inherit from their } \\
\text { elders does not increase" }\end{array}$ \\
\hline
\end{tabular}


NORIAH TASLIM

\begin{tabular}{|c|c|c|c|}
\hline No. & Page & Hikayat Mareskalek & English Translation \\
\hline 34. & 62 & $\begin{array}{l}\text { "Mareskalek pun terkejut, lalu bangun } \\
\text { daripada tidur dengan ketakutannya, } \\
\text { pucat muka, layu badannya" }\end{array}$ & $\begin{array}{l}\text { "Mareskalek startled from sleep, and } \\
\text { awakened with fear; his face pale and his } \\
\text { body weak" }\end{array}$ \\
\hline 35. & 64 & $\begin{array}{l}\text { "Maka tiada rela aku dipanggil orang } \\
\text { akan Susuhunan" }\end{array}$ & $\begin{array}{l}\text { "I do not wish that people call me } \\
\text { Susuhunan" }\end{array}$ \\
\hline 36. & 65 & $\begin{array}{l}\text { "lalu pulang ke Betawi, naik kapal } \\
\text { jalan laut dengan masyghul, hilang } \\
\text { akalnya setengah baki setengah"” }\end{array}$ & $\begin{array}{l}\text { "and he returned to Batavia by ship, } \\
\text { feeling depressed, having lost half his } \\
\text { mind" }\end{array}$ \\
\hline 37. & 65 & $\begin{array}{l}\text { "jika datang seteru, jangan dilawan } \\
\text { berperang di dalam negeri supaya } \\
\text { dipelihara orang kecil jangan mati", }\end{array}$ & $\begin{array}{l}\text { "if the enemy comes, do not fight them } \\
\text { inland so that the common people are safe } \\
\text { and will not be killed" }\end{array}$ \\
\hline 38. & 66 & $\begin{array}{l}\text { "air pasang mesti surut, jika pasang } \\
\text { selama-lamanya, maka tenggelamlah } \\
\text { dunia ini" }\end{array}$ & $\begin{array}{l}\text { "the tide must ebb, if the tide were high } \\
\text { forever, this world would drown" }\end{array}$ \\
\hline 39. & 67 & $\begin{array}{l}\text { "adat dunia ini sudah memang seperti } \\
\text { (roda) kereta, dunia ini berganti-ganti } \\
\text { ke atas ke bawah" }\end{array}$ & $\begin{array}{l}\text { "life in this world is like the (wheels of a) } \\
\text { car, it has its ups and downs" }\end{array}$ \\
\hline 40. & 70 & $\begin{array}{l}\text { "maka Mareskalek itu alim daripada } \\
\text { segala kitab" }\end{array}$ & $\begin{array}{l}\text { "Mareskalek was thoroughly } \\
\text { knowledgeable in all scripture" }\end{array}$ \\
\hline 41. & 73 & $\begin{array}{l}\text { "Hai Mareskalek, burung yang terbang } \\
\text { sangat tinggi itu ke bawah juga } \\
\text { akhirnya dan matahari yang sangat } \\
\text { tinggi itu turun juga nanti, tiada boleh } \\
\text { naik lagi." }\end{array}$ & $\begin{array}{l}\text { "O Mareskalek, the bird that flies on high } \\
\text { must in the end descend, and the sun up } \\
\text { high will also come down some time, } \\
\text { never to rise again." }\end{array}$ \\
\hline
\end{tabular}

